\title{
The Role of Intellectual Property Rights in Agricultural Engineering
}

\author{
P.S. Joshi and S.V. Pathak ${ }^{*}$ \\ Department of Farm Machinery and Power Engineering, College of Agril. Engg. and Tech., \\ Dapoli, India \\ *Corresponding author
}

\begin{abstract}
A B S T R A C T
Keywords

IPRs, Agricultural machinery, Agricultural

technology, Geographic indications, Indian agriculture

Article Info

Accepted:

26 October 2018

Available Online:

10 November 2018

Nowadays, people looking towards the agriculture as industrial point of view or as business, which cannot sustain without research and development and astute investments. In the past three decades, the role of intellectual property rights (IPRs) in agribusiness has increased enormously. Apart from investment in agricultural research, intellectual property rights (IPRs) have profound impact on technology development, and its transfer. There has been an increasing interest in the innovations of pre-harvest as well as post-harvest agriculture machinery. The present paper gives an idea about intellectual property different inventions in agriculture also takes an overview of the current scenario of geographical indications in India.
\end{abstract}

\section{Introduction}

In Indian agriculture, it has some unique characteristics having 250 different crops cultivated in different agro-climatic conditions. In Indian economy, agriculture sector play the crucial role, with 18.5 per cent share in national income; 15 per cent of total exports with two-thirds of work force engaged in this sector. Inputs from agricultural engineering have played dominant role in boosting the productivity and production through appropriate mechanization technique.

In India, agricultural equipment market was valued at Rs. 299.1 billion in the year 2010 and it has tremendous capacity for further growth and development.
Benefits of productivity from farm mechanization and credit facility available in farmers hand has developed the demand for agricultural machinery.

In ancient time, throw back to sixties when inventions of tractors and seed drills were utilized as agriculture machinery.

After a decade, tractors, tractor drawn cultivators, threshers and ploughs were came into existence. Then main focus was on tractors followed by seeders, ploughs and sprayers. From 2000 onwards, the whole inventions were shifted towards increasing mechanization in the pre-harvest and postharvest agriculture machinery (Manchikanti and Sengupta, 2011) 


\section{Intellectual Property (IP)}

Nowadays, in agricultural trade intellectual property is becoming gradually important. Intellectual property is not a physical property, it solely construct of the mind. In the future, innovation along with product differentiation is likely to be important to agricultural industries. In the world markets there is vast competition, the more benefit may accrue to those producers who adopt intellectual property (IP) to the greatest advantage. In such condition, the way the international trading system treats IP will be significantly essential. Without markets there is little incentive to innovate as there are no means to get a return on innovation. In a market context, innovation and information are both judged to be valuable the government allocates property rights over innovations, brands and other forms of IP. The use of IP may be an important element in the success of the agricultural sector in the future (John Asker and Andrew Stoeckel, 1999).

For important forms of IP, simultaneous use by many people creates a problem. Without legal rules, valuable IP could be appropriated by anyone who can get their hands on it. For innovations, this is a problem because it makes it very hard to get a return on R\&D. To sell an innovative idea you need to articulate what that idea is or use the idea to make some other product.

\section{Intellectual Property rights (IPRs)}

Intellectual property rights (IPRs) can be broadly defined as legal rights established over creative or inventive ideas. Intellectual property rights are nothing but bundle of rights, attached to the ownership of abstract creations of the mind, such as the expression in a novel or the innovative step in an invention. (John Asker and Andrew Stoeckel., 1999) There are two main types of IPRs: one, industrial property covering IPRs such as patents, trademarks, geographical indications and industrial designs; two, copyright and related rights covering artistic and literary works, performances, broadcasts.(Jayashree Watal., 1998)

For agricultural research scientists, research directors, policymakers face complex questions and decisions when managing intellectual property rights (IPR). Research programs in developing and developed countries therefore seek clarification on the rights of and access to research innovations (Blakeney et al., 1999).

The types of different IPRs are shown in table 1 . These all types are related to the agriculture sector to protect the goods, machinery and services related to this sector. To be more specific IPRs in agriculture is patents, plant breeder's right, geographical indications, trademark and trade secrets. In industrial sector, banana or potato chips designs are related to the agriculture which is incorporated by machines. But in case of ideas related to the agricultural sector shown on television shows are not considered directly. From long time, machinery has been seen as kind of invention and was protected by IPRs (Kumar and Sinha, 2015).

Both public as well as private sectors are involved in the innovations of agricultural machinery. Organizations like National Innovation Foundation (NAF) and Grassroots Innovations Augmentation Network (GIAN) have helped in the filing patents for innovations and identified commercial mechanism for efficient transfer of technology. The development of innovation of agriculture machinery in tune with these requirements would help pre-harvest and postharvest operations in Indian agriculture.

In India, patenting of agricultural machinery lies in three broad areas such as irrigation, 
plant growth and post-harvest processing. Inventions of tractor has deep category over many years and the paper will focuses growth of different agricultural machinery in these areas. In order to understand the growth of inventions in India, information on applications and granted patent were obtained in Indian Patent Office Web link and Official weekly Publications of the patent office for last 6 years from 2005 to 2010 machinery related to plant growth is largely related to planting tilling and ploughing processes. For irrigation 20 granted patents, for plant growth related machinery are 42 and for post-harvest processing 80 which is more. Year wise distribution of published applications in three major areas of agricultural machinery (Fig.1) assignee wise distribution of published applications is shown in (Fig.2) assignee wise distribution of published applications across categories is shown in (Fig.3) (Manchikanti and Sengupta., 2011)

\section{Agricultural technology}

Technologies relating to varietal development will receive maximum boost among all the agricultural technologies once the protection regime is implemented. Here, agricultural technologies are grouped under different heads such as crop improvement, crop protection, Knowledge based, natural resources management, machinery based and technologies concerning livestock and fisheries.

Application of external inputs such as fertilizers, pesticides, insecticides, weedicides and growth regulators can be used for better crop improvement. Agro-chemicals industry is a multimillion dollar industry worldwide. Current consumption of fertilizers (NPK) of 16 million tones is an eight-fold increase over the 1960s. Growth in the use of insecticides and pesticides has grown exponentially. Natural resources like soil and water are conserved by vegetative and mechanical means or sometimes by combination of these two. Some examples of these measures are farm ponds, contour bunding, zero tillage, terracing, windbreaks, live bunds and reforestation. Patents and copyright can protect such technologies. Farm machinery and implements like tractors, power tillers and threshers will be governed by patents, industrial designs and trademarks. Postharvest technologies relating to processing, storage and various marketing functions will be protected by similar forms of IPRs. Livestock and fisheries enterprises will receive protection by breeders rights, patents, trademarks, copyright, geographic appellations, and industrial design, depending upon the nature of the technology, they will receive protection by either one or a combination of different IPRs listed above. There are some knowledge based technologies including agronomic practices like sowing time, frequency of intercultural operations, spacing time, crop rotations and indigenous technical knowledge. Generally, copyrights govern these technologies. (Ravishankar and Archak, 2000) (Table 2).

\section{Geographical Indications (GI)}

One category of commercial marks more often used in agriculture than industry is geographical indications, including appellations of origin. Every part or region of the world has its name and fame. (Jayashree Watal., 1998) A geographical indication is a sign used on products that have a specific geographical origin, possess qualities as well as reputation that are due to that origin. TradeRelated Aspects of Intellectual Property Rights (the TRIPS Agreement) in 1994, which contains a section on geographical indications (GIs), this form of intellectual property (IP), has attracted increasing attention from policy makers and trade negotiators, as well as producers. 
Table.1 Types of intellectual property rights

\begin{tabular}{|c|c|c|c|c|}
\hline $\begin{array}{l}\text { Intellectual } \\
\text { property rights }\end{array}$ & Types of instruments & Subject matter covered & $\begin{array}{l}\text { Main fields of } \\
\text { application }\end{array}$ & Major international agreements \\
\hline \multirow[t]{5}{*}{$\begin{array}{l}\text { Industrial } \\
\text { property }\end{array}$} & Patents & $\begin{array}{l}\text { New, Non- obvious, } \\
\text { indigenous application inventions }\end{array}$ & Manufacturing & $\begin{array}{l}\text { Paris Convention Patent } \\
\text { Cooperation Treaty, Budapest }\end{array}$ \\
\hline & Utility models & Functional designs & & Treaty Strasbourg Agreement \\
\hline & Industrial designs & Ornamental designs & & Hague Agreement \\
\hline & Trademark & $\begin{array}{l}\text { Signs or symbols to identify } \\
\text { goods and services }\end{array}$ & & Nice Agreement \\
\hline & Geographical Indications & & & Lisbon Agreement \\
\hline $\begin{array}{l}\text { Literary and } \\
\text { Artistic Property }\end{array}$ & $\begin{array}{l}\text { Copyrights and } \\
\text { neighbouring rights }\end{array}$ & Original works of authorships & $\begin{array}{l}\text { Printing, } \\
\text { entertainment, } \\
\text { audio, video, etc. }\end{array}$ & $\begin{array}{l}\text { Berne Convention } \\
\text { Rome Convention } \\
\text { Geneva Convention } \\
\text { Brussels Convention }\end{array}$ \\
\hline $\begin{array}{l}\text { Sui Generis } \\
\text { Protection }\end{array}$ & Breeders' right & $\begin{array}{l}\text { New, stable homogenous, } \\
\text { distinguishable varieties }\end{array}$ & $\begin{array}{l}\text { Agriculture and } \\
\text { food security }\end{array}$ & $\begin{array}{l}\text { Union for Protection of Plant } \\
\text { varieties (UPOV) }\end{array}$ \\
\hline Trade Secrets & Integrated circuits & $\begin{array}{l}\text { Original layout designs } \\
\text { Secret business knowledge }\end{array}$ & $\begin{array}{l}\text { Micro electronic } \\
\text { industry } \\
\text { All industries }\end{array}$ & Washington Treaty \\
\hline \multicolumn{3}{|c|}{ Source: WIPO, 1995} & & Activate Windows \\
\hline
\end{tabular}

Table:

Categorisation Matrix of Interplay and Implications

\begin{tabular}{|c|c|c|c|c|c|c|}
\hline \multirow[t]{2}{*}{ Technologies } & \multirow{2}{*}{$\begin{array}{l}\text { Intellectual Property } \\
\text { Rights applicable }\end{array}$} & \multicolumn{2}{|c|}{ Investors/Actors } & \multicolumn{3}{|c|}{ Implications } \\
\hline & & Public & Private & Social & Economic & Ecological \\
\hline \multicolumn{7}{|c|}{ D. Machinery-based technologies } \\
\hline $\begin{array}{l}\text { Farm Machinery \& } \\
\text { Power }\end{array}$ & Patents. ID \& TM & • & 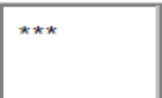 & -+ & ++ & +- \\
\hline $\begin{array}{l}\text { Post-Harvest } \\
\text { Technologies }\end{array}$ & Patents. ID \& TM & .. & • & ++ & ++ & ++ \\
\hline $\begin{array}{l}\text { E.. Livestock and } \\
\text { Fisheries }\end{array}$ & $\begin{array}{l}\text { Patents. PBRs. ID. } \\
\text { CR. TM }\end{array}$ & ** & .. & ++- & ++ & -- \\
\hline
\end{tabular}

Source: Authors

NOTE: 1. Number of asterisks denotes the magnitude of impact.

2. Number of +'s and -'s represents the magnitude of positive and negative impacts.

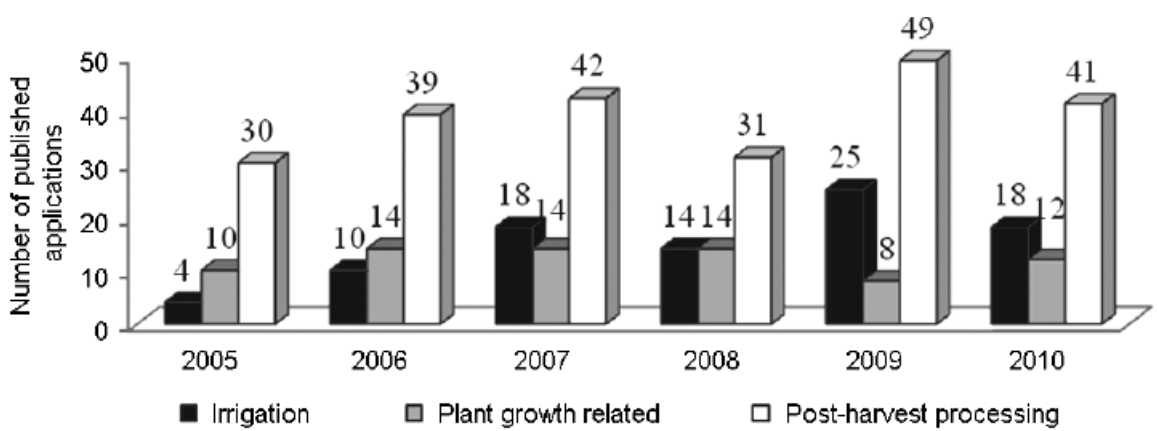

Fig. 1 - Year wise distribution of published applications in three major areas of agricultural machinery 


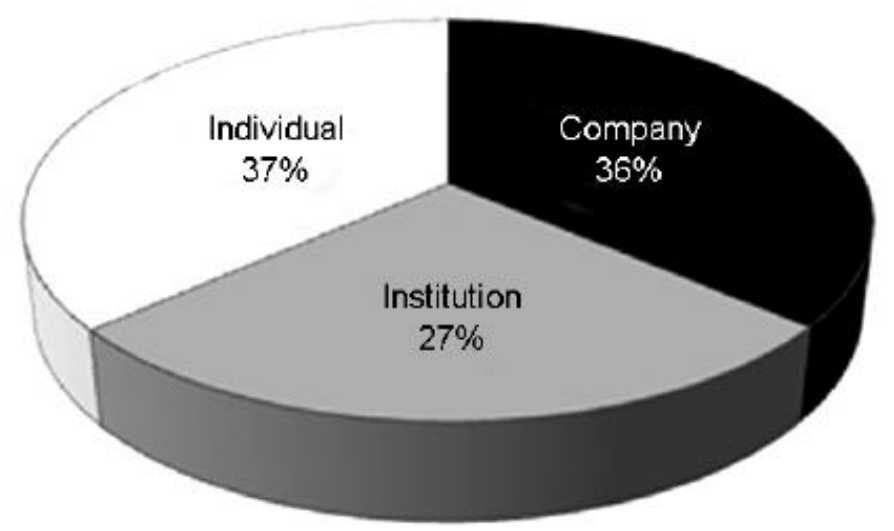

Fig. 2 - Assignee wise distribution of published applications

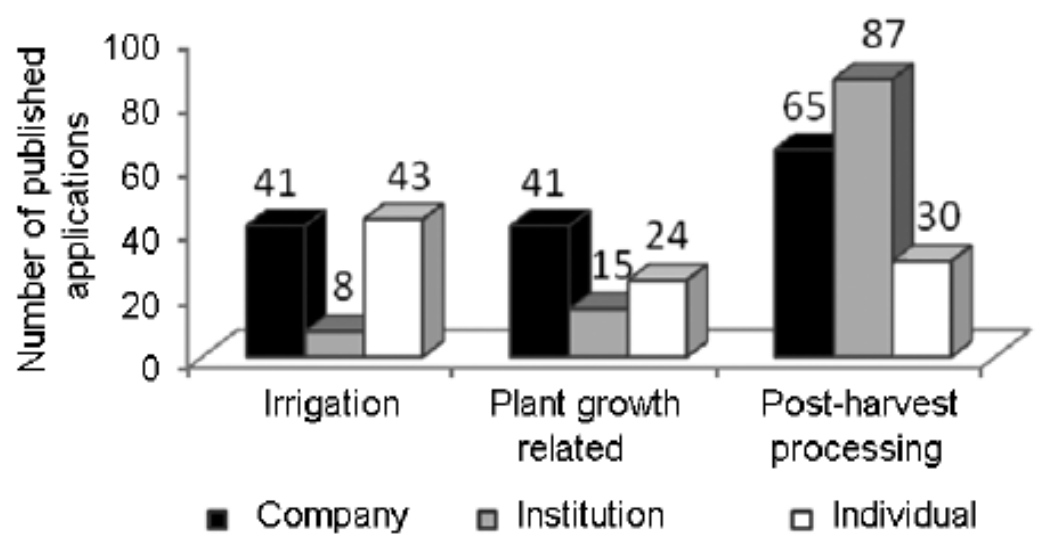

Fig. 3 - Assignee wise distribution of published applications across categories

Table.2 Economic advantage of mechanization (in per cent)

Increase in productivity

Seed-cum-fertilizer drill facilitates

Saving in seeds 20

Saving in fertilizer

Enhancement in cropping intensity

$5-22$

Increase in gross income of the farmers

$29-49$

Source: Report of the sub-group on agricultural implements and machinery for formulation of IX Five Year Plan, Govt of India 
Table.3 Type of Product Wise Distribution of GIs Registered In India

\begin{tabular}{|c|l|c|c|}
\hline $\begin{array}{c}\text { Sr. } \\
\text { No. }\end{array}$ & Type of product & $\begin{array}{c}\text { No. of GI } \\
\text { registered }\end{array}$ & Percentage \\
\hline 1 & Tea & 02 & 7.41 \\
\hline 2 & Textiles & 13 & 48.15 \\
\hline 3 & Incense Sticks & 01 & 3.7 \\
\hline 4 & Metal mirror & 01 & 3.7 \\
\hline 5 & Horticulture Product & 03 & 11.11 \\
\hline 6 & Essential Oil & 01 & 3.7 \\
\hline 7 & Soap & 01 & 3.7 \\
\hline 8 & Handicrafts & 03 & 11.11 \\
\hline 9 & Wet Grinder & 01 & 3.7 \\
\hline 10 & Painting Total & 01 & 3.7 \\
\hline & \multicolumn{2}{|l}{} \\
\hline
\end{tabular}

Table.4 State Wise Distribution of Geographical Indications Registered in India

\begin{tabular}{|c|l|c|c|}
\hline $\begin{array}{c}\text { Sr. } \\
\text { No. }\end{array}$ & \multicolumn{1}{|c|}{ State } & $\begin{array}{c}\text { No. of GI } \\
\text { registered }\end{array}$ & Percentage \\
\hline 1 & West Bengal & 1 & 3.70 \\
\hline 2 & Andhra Pradesh & 1 & 3.70 \\
\hline 3 & Madhya Pradesh & 1 & 3.70 \\
\hline 4 & Orissa & 1 & 3.70 \\
\hline 5 & Rajasthan & 1 & 3.70 \\
\hline 6 & Tamil Nadu & 5 & 18.52 \\
\hline 7 & Karnataka & 12 & 44.44 \\
\hline 8 & Kerala & 1 & 3.70 \\
\hline 9 & Maharashtra & 2 & 7.41 \\
\hline 10 & Himachal Pradesh & 2 & 7.41 \\
\hline & & 27 & 100 \\
\hline
\end{tabular}


Since the qualities or properties of the product depend on the geographical place of production, there is a link between the product and its original place of production. Agricultural products mainly have properties that derive from their place of production which are influenced by specific local, geographical factors such as soil and climate. So that it is not surprising the majority of GIs throughout the world are applied to agricultural products, foodstuffs, spirit drinks and wine. A GI also highlight the specific qualities of a product that are due to human factors found in the product's place of origin, such as traditions and specific manufacturing skills. For handicrafts, generally handmade using local natural resources also usually embedded in the traditions of local communities. Geographical indications thus play a key element in developing brands for quality-bound-to-origin products. Consumer focuses more towards the geographical origin product. Consumers are also ready to pay more in case of these GI products (Table 3).

This has favored the development of specific markets for products with certain properties linked to their place of origin. Products identified by a GI are often the result of traditional processes and knowledge which is carry forward by a community in a particular region from generation to generation. A GI's reputation is a collective, intangible asset. (Anonymous, 2007)

An effective protection for GIs was of considerable importance for a country like India, which was richly endowed with natural and agricultural products and which already had in its possession renowned geographical names such as 'Darjeeling'(tea), 'Alphonso' (mango), 'Basmati' (rice), etc., there was no separate legislation on GIs until the enactment of 'The Geographical Indications of Goods (Registration and Protection) Act, 1999' (henceforth the GI Act) (Hirwade and
Hirwade, 2006). It has been observed from Table 4 that in India, the maximum 12 geographical indications are registered by Karnataka forming $44.44 \%$ followed by 5 from Tamil Nadu with $18.52 \%$. The maximum GIs registered are from Textiles category i.e. 13 forming $48.15 \%$ of the total registration followed by Horticulture and Handicrafts with $11.11 \%$ each.

\section{Probable geographical indications}

Examples of possible Indian Geographical Indications are Basmati Rice, Alphanso Mango, Nagpur Orange, KolhapuriChappal, BikaneriBhujia, Agra Petha, Paithani and Banaras Saree, Feni (Liquor from Goa), LonavalaChikki, TirunelveliHalwa, Mysore Rasam, etc.

Technology will drive future growth in Indian agriculture. The selection of types of protection to be applied to agricultural research innovations is a complicated management decision. Geographical Indications is an emerging field of Intellectual property. Every region has its claim to fame and it has to be protected. Intellectual property rights have never been more economically and politically important or controversial than they are today. Creative collaborations for the purpose of product development commercialization and implementation by adopting new technologies in different regions will give the significant boost to this sector. In a knowledge based economy, there is no doubt that an understanding of IPRs is mandatory to informed policy making in all areas of human development.

\section{References}

Annonymous, 2007. Geographical Indications An Introduction. World Intellectual Property Organization. 
Asker, John and Andrew, Stoeckel., 1999. Intellectual property in agricultural trade. Rural Industry Research and Development Corporation.

Blakeney, Michael, Joel I. Cohen, and Stephen Crespi., 1999. Intellectual Property Rightsand Agricultural Biotechnology. Managing Agricultural Biotechnology. Addressing Research Program Needs and Policy Implications.

Jayashree, Watal, 1998. Intellectual property rights in Indian agriculture. Indian council for research on international economic relations, working paper no.44.
Kumar, Vilas and Kunal, Sinha, 2015. Status and Challenges of Intellectual Property Rights in Agriculture Innovation in India. Journal of Intellectual Property Rights., vol 20. pp 288-296.

Manchikanti, Padmavati and Mahasweta Sengupta., 2011. Agricultural Machinery in India: IPR Perspective. Journal of Intellectual Property Rights., vol 16. pp 163-169.

Ravishankar, A. and Sunil, Archak, 2000. Policy brief. IPRs and agricultural technology: interplay and implications for India.

\section{How to cite this article:}

Joshi, P.S. and Pathak, S.V. 2018. The Role of Intellectual Property Rights in Agricultural Engineering. Int.J.Curr.Microbiol.App.Sci. 7(11): 3151-3158.

doi: https://doi.org/10.20546/ijcmas.2018.711.362 